\title{
Development of a nested polymerase chain reaction for amplification of a sequence of the p57 gene of Renibacterium salmoninarum that provides a highly sensitive method for detection of the bacterium in salmonid kidney
}

\author{
Dorothy M. Chase, Ronald J. Pascho* \\ U.S. Geological Survey, Biological Resources Division, Western Fisheries Research Center, 6505 N.E. 65th Street, Seattle, \\ Washington 98115, USA
}

\begin{abstract}
Nucleic acid-based assays have shown promise for diagnosing Renibacterium salmoninarum in tissues and body fluids of salmonids. Development of a nested polymerase chain reaction (PCR) method to detect a 320 bp DNA segment of the gene encoding the p57 protein of $R$. salmoninarum is described. Whereas a conventional PCR for a $383 \mathrm{bp}$ segment of the p57 gene reliably detected $1000 R$. salmoninarum cells per reaction in kidney tissue, the nested PCR detected as few as $10 R$. salmoninarum per reaction in kidney tissue. Two DNA extraction methods for the nested PCR were compared and the correlation between replicate samples was generally higher in samples extracted by the QIAamp system compared with those extracted by the phenol/chloroform method. The specificity of the nested PCR was confirmed by testing DNA extracts of common bacterial fish pathogens and a panel of bacterial species reported to cause false-positive reactions in the enzymelinked immunosorbent assay (ELISA) and the fluorescent antibody test (FAT) for $R$. salmoninarum. Kidney samples from 74 naturally infected chinook salmon were examined by the nested PCR, the ELISA, and the FAT, and the detected prevalences of $R$. salmoninarum were 61,47 , and $43 \%$, respectively.
\end{abstract}

KEY WORDS: Polymerase chain reaction - Renibacterium salmoninarum - p57 protein - Bacterial kidney disease BKD detection

\section{INTRODUCTION}

All salmonid fish species are susceptible to infection by Renibacterium salmoninarum, the causative agent of bacterial kidney disease (BKD; Evenden et al. 1993, Fryer \& Lannan 1993). $R$. salmoninarum produces a $57 \mathrm{kDa}$ (p57) protein that is responsible for cell surface hydrophobicity and virulence (Daly \& Stevenson 1987 Bruno 1988). The p57 protein and its breakdown products are the predominant components of the extracellular protein (ECP) fraction released by $R$. salmoninarum into the surrounding tissues and body

•E-mail: ron_pascho@usgs.gov fluids during an infection (Griffiths \& Lynch 1991, Rockey et al. 1991). The levels of the ECP generally correlate with the severity of an $R$. salmoninarum infection (Pascho et al. 1991)

Because of the fastidious nature and slow replication of Renibacterium salmoninarum in bacteriological culture, primary isolation of the bacterium is impractical for routine diagnosis (Benediktsdóttir et al. 1991, Gudmondsdóttir et al. 1991). The fluorescent antibody test (FAT) or the enzyme-linked immunosorbent assay (ELISA) are commonly used to measure the prevalence and levels of $R$, salmoninarum infection among fish from affected populations (Pascho et al. 1991, Maule et al. 1996, Elliott et al. 1997). The FAT relies on observation of $R$. salmoninarum stained by fluorescein- 
labelled specific immunoglobulin, whereas the ELISA uses immunoglobulin to quantify the levels of the p57 protein (Rockey et al. 1991) or components of the ECP fraction (Pascho \& Mulcahy 1987, Meyers et al. 1993). The ELISA is considered more sensitive than bacteriological culture or the FAT for detecting $R$. salmoninarum (Dixon 1987, Pascho et al. 1987, Gudmundsdóttir et al. 1993, Jansson et al. 1996) and is more likely to identify fish with asymptomatic infections than the FAT (Meyers et al. 1993).

Nucleic acid probes (Mattsson et al. 1993, León et al. 1994a, Hariharan et al. 1995), and the polymerase chain reaction (PCR; Brown et al. 1994, León et al. 1994b, McIntosh et al. 1996, Pascho et al. 1998) can be used to detect Renibacterium salmoninarum in tissues and fluids from infected fish. The PCR has the greatest potential for improving both the sensitivity and specificity of detection of $R$. salmoninarum by the enzymatic amplification of a unique genome sequence (Saiki 1992). McIntosh et al. (1996) and Brown et al. (1994) developed PCR methods to detect different segments of the gene encoding the p57 protein. McIntosh et al. (1996) were able to amplify DNA in fish tissue when the $R$. salmoninarum concentration was between 62.5 and 125 cells, which they believed to be about 1 order of magnitude greater sensitivity than the ELISA described by Meyers et al. (1993). Brown et al. (1994) used a PCR to test the contents of untreated coho salmon $O$. kisutch and chinook salmon $O$. tshawytscha eggs, and from coho salmon eggs injected with known quantities of $R$. salmoninarum cells. In that study, $R$. salmoninarum DNA was detected by the PCR in eggs from parent fish that had been categorized as $R$. salmoninarum-negative on the basis of testing kidney tissue by the ELISA and the FAT. The authors were also able to detect $R$. salmoninarum DNA in coho salmon eggs injected with as few as 2 bacterial cells.

Improved sensitivity has been obtained from the PCR method by using a 2-step, or nested, amplification of specific DNA or RNA sequences when testing for some fish pathogenic microorganisms (Barlough et al. 1995, Mooney et al. 1995). For the nested PCR, the first set of primers is used to amplify a sequence of nucleic acids that includes an internal target DNA or RNA sequence. The PCR product from the first round reaction is then used as a template with a second set of primers that will amplify only the target nucleic acid sequence. We recently used a nested PCR to confirm an inhibitory effect by components of ovarian fluid on detection of the ECP of Renibacterium salmoninarum by the ELISA (Pascho et al. 1998). Surprisingly, we were able to amplify a region of the gene encoding the p57 protein from every ovarian fluid sample tested, even those that had neither detectable levels of the ECP by the ELISA, nor detectable $R$. salmoninarum cells by the membrane-filtration FAT. Magnússon et al. (1994) described a nested PCR based on amplification of 2 sequences of the $16 \mathrm{~S}$ ribosomal RNA of $R$. salmoninarum that could detect 1 to 10 bacterial cells in ovarian fluid from naturally infected Atlantic salmon Salmo salar. Detection of $R$. salmoninarum in kidney tissue, however, was unreliable because of uncharacterized inhibitors in that tissue.

In this report, we describe the development of the nested PCR method for detecting a 320 bp DNA segment of the gene encoding the p57 protein of Renibacterium salmoninarum, and its suitability for testing fish tissue homogenates without compromising sensitivity. We found that the nested PCR was more sensitive than a conventional PCR for detection of $R$. salmoninarum in kidney tissue. We also compared the nested PCR with the FAT and the ELISA for detecting $R$. salmoninarum in kidney tissue of naturally infected chinook salmon.

\section{MATERIALS AND METHODS}

Bacteria. Renibacterium salmoninarum, ATCC 33209, was grown in KDM 2 (Evelyn 1977) broth containing $10 \%(\mathrm{v} / \mathrm{v})$ fetal bovine serum at $15^{\circ} \mathrm{C}$. The bacterial suspension was centrifuged at $5000 \times \mathrm{g}$ for $20 \mathrm{~min}$. Cells were resuspended in phosphate buffered saline, $\mathrm{pH} 7.4$ (PBS) and stored at $4^{\circ} \mathrm{C}$. The concentration of $R$. salmoninarum was quantified by the membranefiltration FAT (MF-FAT) procedure of Elliott \& Barila (1.987) with modifications as described by Elliott \& McKibben (1997).

Cultures of Corynebacterium aquaticum (ATCC 14665), Pseudomonas fluorescens (provided by J. S. Foott, U.S. Fish and Wildlife Service), Carnobacterium piscicola (ATCC 35586), Aeromonas hydrophila (ATCC 14715), Aeromonas salmonicida (ATCC 14174), Yersinia ruckeri (ATCC 29473), and Vibrio anguillarum (ATCC 19264) were grown in brain heart infusion (BHI) broth for $24 \mathrm{~h}$ at $25^{\circ} \mathrm{C}$. Serial 10 -fold dilutions of each bacterial suspension were prepared in a diluent containing $0.1 \%(\mathrm{w} / \mathrm{v})$ peptone and $0.85 \%(\mathrm{w} / \mathrm{v})$ sodium chloride, and aliquots of each dilution were inoculated onto $\mathrm{BHI}$ agar plates for $24 \mathrm{~h}$ at $25^{\circ} \mathrm{C}$. The concentration of viable cells in a given suspension was calculated based on the number of colonies observed at one dilution. A culture of Rothia dentocariosa (ATCC 17931) was grown in tryptic soy broth for $24 \mathrm{~h}$ at $37^{\circ} \mathrm{C}$. The concentration of viable cells was determined as described above except the bacterial suspension was inoculated onto tryptic soy agar plates for $24 \mathrm{~h}$ at $37^{\circ} \mathrm{C}$.

Fish. Male and female spring chinook salmon Oncorhynchus tshawytscha used in this study spawned at Carson National Fish Hatchery, Carson, Washington 
(U.S. Fish and Wildlife Service), during the fall of 1994. Juvenile coho salmon $O$. kisutch, averaging $10 \mathrm{~g}$, were obtained from Willard National Fish Hatchery, Cook, Washington during April 1994 and reared at the Western Fisheries Research Center (U.S. Geological Survey) in Seattle, Washington, in pathogen-free fresh water at an average temperature of $12^{\circ} \mathrm{C}$

Tissue preparation. To obtain tissue samples for the ELISA and the FAT, fish were killed by exposure to an overdose of MS 222 (Argent, Redmond, WA, USA).

The entire kidney from each coho salmon was removed aseptically and pooled for testing by the ELISA and FAT. Each tissue pool was homogenized without dilution, then diluted $1: 4(\mathrm{w} / \mathrm{v})$ in $0.01 \mathrm{M}$ PBS, pH 7.4 containing $0.05 \%(\mathrm{v} / \mathrm{v})$ Tween 20 (PBS-T20). Anterior, mid and posterior sections of the kidney from each spring chinook salmon were aseptically removed and homogenized for testing by the ELISA and FAT. Each kidney homogenate was diluted $1: 4(\mathrm{w} / \mathrm{v})$ in PBS-T20 The kidney homogenates were stored at $-70^{\circ} \mathrm{C}$.

ELISA. A double-antibody ELISA that measures the levels of a soluble antigen fraction of Renibacterium salmoninarum (Pascho et al. 1991, ELISA II) was used to test the kidney homogenates. The positive-negative threshold absorbances were calculated as described by Pascho et al. (1987). The positive-negative cutoff absorbance for kidney tissue was 0.091. Kidney tissue samples that tested positive were assigned the following antigen-level categories: low, 0.092 to 0.199 medium, 0.200 to 0.999 ; and high, $\geq 1.000$.

Direct FAT. Renibacterium salmoninarum were counted in kidney homogenates by the smear FAT procedure of Pascho et al. (1987). Affinity-purified goat anti- $R$. salmoninarum immunoglobulin conjugated with fluorescein isothiocyanate (Kirkegaard and Perry Laboratories, Inc., Gaithersburg, MD, USA) was used for each FAT at a working dilution of 1:40 (v/v). Smears were examined at $1000 \times$ magnification and the number of $R$. salmoninarum in 100 microscope fields was tabulated for each fish.

The concentrations of Renibacterium salmoninarum resuspended in PBS were quantified by the MF-FAT. Fluorescing $R$. salmoninarum were counted in 150 microscope fields at a $1000 \times$ magnification.

DNA extraction. Two methods of nucleic acid extraction were used in this study. The first extraction method was a standard procedure for nucleic acid preparation with phenol/chloroform. The phenol/ chloroform method described in Pascho et al. (1998) was used to prepare DNA from a $250 \mu$ l Renibacterium salmoninarum suspension. The concentration of DNA was determined spectrophotometrically at $260 \mathrm{~nm}$ and the preparation was stored at $-20^{\circ} \mathrm{C}$.

The second method of DNA extraction used the QIAamp tissue kit for DNA purification (Qiagen Inc.,
Chatsworth, CA, USA). For Renibacterium salmoninarum, a $250 \mu$ bacterial suspension was prepared for PCR according to the manufacturer's instructions for tissue samples except that the samples were initially incubated with $180 \mu \mathrm{l}$ of $20 \mathrm{mg} \mathrm{m}^{-1}$ lysozyme; $20 \mathrm{mM}$ Tris- $\mathrm{HCl}_{1} \mathrm{pH} 8.0 ; 2 \mathrm{mM}$ EDTA and $1.2 \%$ Triton (v/v) at $37^{\circ} \mathrm{C}$ for $1 \mathrm{~h}$. The concentration of DNA was determined spectrophotometrically at $260 \mathrm{~nm}$ and the preparation was stored at $-20^{\circ} \mathrm{C}$.

Sensitivity of nested and conventional PCR. To compare the nested PCR with a conventional PCR, various concentrations of Renibacterium salmoninarum were mixed with a buffer or with homogenized kidney tissue from a coho salmon with undetectable levels of $R$ salmoninarum on the basis of prior testing by the ELISA, FAT, and nested PCR. A $100 \mu$ aliquot of $R$. salmoninarum from each concentration group was mixed with either $900 \mu$ l of the kidney tissue homogenate or with $900 \mu \mathrm{l}$ of $10 \mathrm{mM}$ hydroxymethyl aminomethane hydrochloride (Tris-HCl) pH 8.0, $1 \mathrm{mM}$ ethylenediaminetetraacetic acid (EDTA) pH 8.0 (TE buffer), to give final concentrations from $4 \times 10^{1}$ to $4 \times 10^{8}$ bacterial cells per ml. Each sample was prepared for PCR by the 2 extraction methods described above. In the conventional PCR and nested PCR, 0.2 to $0.8 \mu \mathrm{g}$ of purified nucleic acid was used as template DNA. The nested PCR was performed according to a previously described protocol (Pascho et al. 1998) using primers designed to amplify segments of the gene encoding the p57 protein of $R$. salmoninarum. Gels were examined under UV illumination and nested PCR samples were considered positive if the anticipated 320 base pair (bp) product was observed.

The conventional PCR was carried out by using the same reaction mixture and thermal cycler profile as the first round of the nested PCR described in Pascho et al. (1998) but with 35 cycles. PCR samples were examined by gel electrophoresis and the samples were considered positive if the anticipated 383 bp product was observed

Specificity of primers for Renibacterium salmoninarum. To ascertain the specificity of the nested PCR, DNA was extracted from $1 \mathrm{ml}$ samples of PBS suspensions containing $1 \times 10^{6}$ bacterial cells for each genus listed above. The samples were extracted using the QIAamp tissue kit. The DNA was extracted according to the manufacturer's instructions except that the bacteria were pelleted by centrifugation at $8000 \times g$ for $20 \mathrm{~min}$ at $4^{\circ} \mathrm{C}$ and the pellet was incubated with $180 \mu \mathrm{l}$ of $20 \mathrm{mg} \mathrm{ml}^{-1}$ lysozyme; $20 \mathrm{mM}$ Tris- $\mathrm{HCl}, \mathrm{pH}$ 8.0; $2 \mathrm{mM}$ EDTA and $1.2 \%(\mathrm{v} / \mathrm{v})$ Triton at $37^{\circ} \mathrm{C}$ for $1 \mathrm{~h}$. In the nested PCR, $0.2 \mu \mathrm{g}$ of purified nucleic acid served as template DNA.

Comparison of the ELISA, the FAT and the nested PCR with naturally infected tissues. The kidney from 
each of 74 spring chinook salmon was tested by the ELISA, the FAT and the nested PCR. The ELISA and FAT were performed on kidney homogenates as described above. Purified DNA from kidney was prepared by the phenol/chloroform extraction method described above and $10 \mu \mathrm{l}$ of this material was used as template DNA in the nested PCR.

\section{RESULTS}

\section{Sensitivity of nested and conventional PCR}

The relative sensitivities of the conventional and the nested PCRs were not affected by the type of extraction method used to purify the nucleic acids. The detection limit of the conventional PCR was 10 Renibacterium salmoninarum per reaction in TE buffer and 1000 R. salmoninarum per reaction in kidney homogenate. The detection limit for the nested PCR was 10 $R$. salmoninarum per reaction when the diluent was either TE buffer or kidney homogenate (Fig. 1). The proportion of fish in which $R$. salmoninarum was detected by the nested PCR in both replicate kidney tissue samples was generally higher in samples extracted by the QIAamp method ( $\mathrm{p}=0.057$ ). The proportions of fish categorized as $R$. salmoninarumpositive in both replicate tissue samples were 82 and $96 \%$ by the phenol/chloroform and QIAamp extraction methods, respectively.

\section{Specificity of primers}

No amplification products were observed when DNA samples from Corynebacterium aquaticum, Pseudomonas fluorescens, Carnobacterium piscicola, Aeromonas hydrophila, Aeromonas salmonicida, Yersinia ruckeri, Vibrio anguillarum, and Rothia dentocariosa were tested in the nested PCR. The predicted $320 \mathrm{bp}$ product was consistently amplified from the $R$. salmoninarum DNA.

\section{Comparison of the ELISA, the FAT and the nested $P C R$ with naturally infected tissues}

The prevalences of Renibacterium salmoninarum in the kidney samples on the basis of testing by the nested PCR, the ELISA and the FAT were $61 \%(45 / 74)$, $47 \%(35 / 74)$, and $43 \%(32 / 74)$, respectively (Table 1 ). About $41 \%$ (30/74) of the fish were categorized as positive by all 3 assays. Among the kidney homogenates that tested negative by the FAT and the ELISA, $14 \%$ (10/74) were positive by the nested PCR. Approxi-

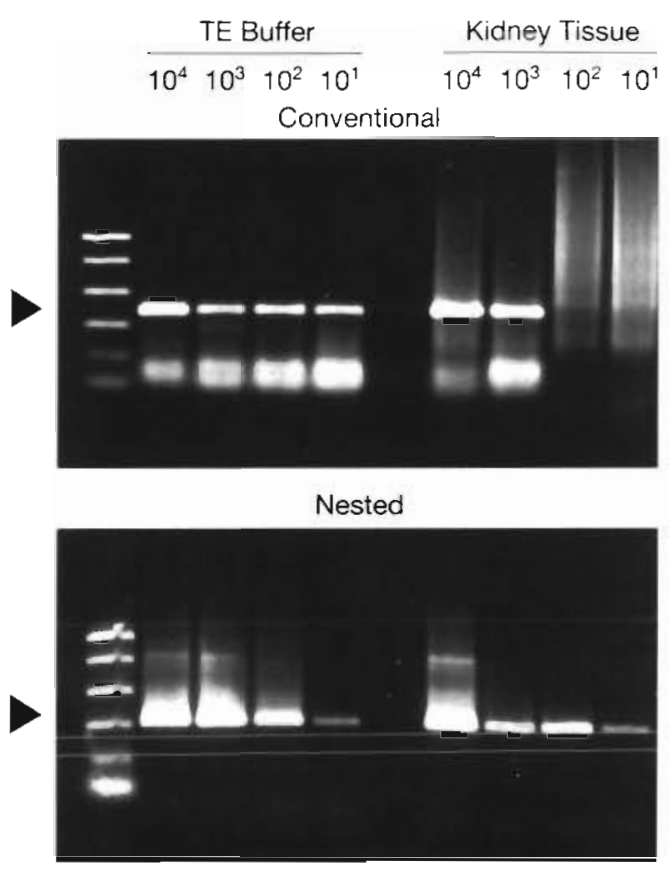

Fig. 1. Comparison of the detection thresholds of the conventional PCR and the nested PCR for Renibacterium salmoninarum. Bacterial cells were diluted in either TE buffer or in homogenized kidney tissue from coho salmon, then DNA was extracted from each sample using the QIAamp tissue kit. The number of $R$. salmoninarum cells in a given reaction mixture is shown above the appropriate lane. Arrowheads indicate positions of the $383 \mathrm{bp}$ PCR product (top), and the $320 \mathrm{bp}$ nested PCR product (bottom)

mately $36 \%(27 / 74)$ of the samples tested negative by all 3 tests. Two samples were positive by the FAT, and negative by the ELISA and the nested PCR. The numbers of bacteria detected by the FAT in these samples were 1 and $2 R$. salmoninarum in 100 microscope fields, respectively.

Table 1. Comparison of the nested PCR, the ELISA, and the FAT for the detection of Renibacterium salmoninarum in 74 kidney samples from chinook salmon Oncorhynchus tshawytscha. ELISA infection-level categories are described in the text

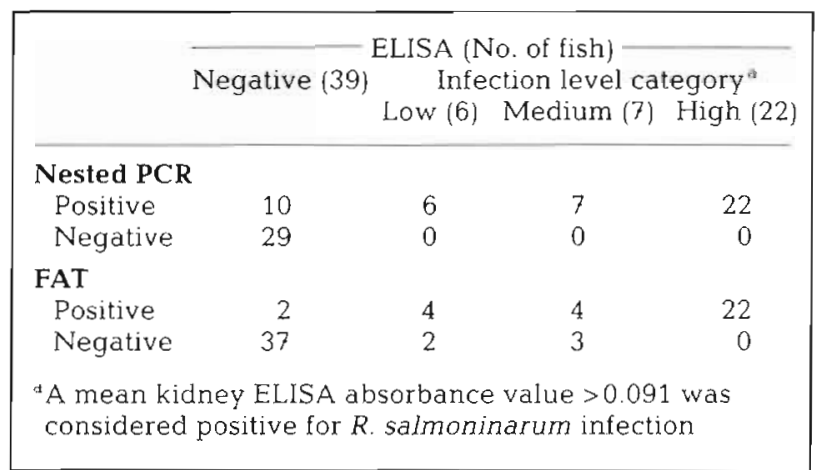


The prevalences of Renibacterium salmoninarum were very similar by the ELISA and the FAT, possibly because about one-half of the kidney samples were categorized as having high levels of $R$. salmoninarum on the basis of both tests; the proportions of fish with high infection levels on the basis of an ELISA absorbance $\geq 1.000$ or cell numbers too-numerous-to-count by the FAT were $30 \%(22 / 74)$ and $27 \%$ (20/74), respectively. However, about $39 \%(5 / 13)$ of the kidney samples categorized as having low or medium antigen levels on the basis of the ELISA were negative by the FAT.

\section{DISCUSSION}

We describe the development of a nested PCR for amplification of a segment of the gene encoding the p57 protein of Renibacterium salmoninarum. We found that detection of $R$. salmoninarum in fish tissues was improved 100-fold with a nested PCR compared to a single amplification PCR. Similar results have been reported for other bacteria diagnosed by conventional and nested PCRs (Mooney et al. 1995, Lee et al. 1997. Miriam et al. 1997). Magnússon et al. (1994) reported difficulties, however, when testing kidney tissue from Atlantic salmon in a nested, reverse-transcription PCR (rtPCR) based upon a $16 \mathrm{~S}$ rRNA sequence of $R$. $5 \mathrm{al}$ moninarum. The authors believed the inconsistent results they observed when testing kidney tissue were related to incomplete lysis of the bacterium and inhibition of the Taq polymerase by unspecified factors in the tissue. These results might also be explained by degradation of the target sequence of $R$. salmoninarum RNA by kidney RNAases present during the extraction procedure. In addition, the inhibitors in the kidney tissues could interfere with reverse transcription in their nested rtPCR. Neither of these is a factor in our DNA-based nested PCR assay. In our study, the conventional PCR was unable to produce an observable product below 1000 bacterial cells per reaction when the $R$. salmoninarum were diluted in kidney tissue. This may reflect an inability of the conventional PCR to compensate for incomplete lysis of all the bacteria in a given sample. In contrast to the rtPCR of Magnússon et al. (1994), we are amplifying DNA in both steps of our nested PCR, which may provide an advantage when there are very small amounts of template DNA. The QIAamp system generally gave the most consistent results between replicate samples, and offered a nontoxic alternative to the conventional extraction methods that use phenol/chloroform. In addition, the QIAamp system reduces the need for lengthy extraction procedures involving multiple steps, each of which increases the risk of cross contamination between samples or the loss of template DNA.
The 2-step amplification of a nested PCR also serves to enhance the specificity of the test because the product from the Renibacterium salmoninarum genome produced by the initial amplification acts as a template and thus must contain binding sites for the internal primers used in the second round of amplification (Porter-Jordon et al. 1990). The accuracies of serologically based diagnostic methods for $R$. salmoninarum, such as the ELISA and the FAT, have been under question because of reports of cross-reacting bacteria (Austin et al. 1985, Dixon 1985, Bandín et al, 1993 , Brown et al. 1995, Wood et al. 1995). The criteria by which we selected bacteria to confirm the specificity of the primers used in the nested PCR were that a given bacterium must either be a common bacterial pathogen of salmonids, or a species reported previously to produce false-positive reactions in the ELISA. Our results support those of others (Mattsson et al. 1993, Brown et al. 1995, Hariharan et al. 1995) that nucleic acid-based assays may be used to accurately diagnose $R$. salmoninarum if one selects primers that amplify a DNA sequence that is unique to the kidney disease bacterium. Primer specificity, however, is only one factor in avoiding false-positive reactions in a nested PCR. Erroneous results may also occur if adequate care is not taken to prevent contamination of samples with amplified product from earlier analyses. We have adopted many of the guidelines suggested (Kwok \& Higuchi 1989) to eliminate the potential for carryover of amplified product from an R. salmoninarum-positive sample into reaction mixtures of other samples

An additional benefit from nucleic acid-based diagnostic tests, such as the nested PCR described in this report, is the potential for significant increases in sensitivity. The PCR-based assays for Renibacterium salmoninarum have been reported to be one or more orders of magnitude greater in sensitivity than conventional serological tests (McIntosh et al. 1996. Miriam et al. 1997). We believe that our nested PCR can reliably detect about $10 \mathrm{R}$. salmoninarum per reaction, making it between 10 - and 100 -fold more sensitive than the ELISA used in this study. This would help to explain why we were able to detect $R$. salmoninarum in about $26 \%(10 / 39)$ of the kidney samples categorized as negative by the ELISA. It is interesting, however, that there were no samples positive by the ELISA and negative by the nested PCR. The ELISA can detect circulating soluble antigens (Pascho et al. 1987, 1991) shed from $R$. salmoninarum at infection sites in other tissues or organs. In contrast, the nested PCR probably requires the presence of $R$. salmoninarum in the test sample because extracellular bacterial DNA released from other infection sites may be degraded rapidly (Benvenisty \& Reshef 1986). Unfortunately, samples of 
other organs or body fluids from the 29 fish that were negative by the nested PCR were not available for analysis in the ELISA.

Although PCR-based assays make novel and more sensitive approaches for studying the epizootiology of Renibacterium salmoninarum possible, the biological significance of positive PCR results from fish otherwise believed to be free of the bacterium is poorly understood. It is generally assumed that the probability of vertical transmission of $R$. salmoninarum is related to the level of infection in the female parent (Evelyn et al. 1986, Pascho et al. 1991) and that vertical transmission is more likely when the infection levels are extremely high. The results of our comparison of methods to detect $R$. salmoninarum in ovarian fluid (Pascho et al. 1998), and those of Brown et al. (1994) suggest that the prevalence of $R$. salmoninarum among eggs of mating pairs from populations in which BKD is enzootic may be far greater than anticipated. Others have cautioned, however, that PCR-positive samples may contain some proportion of dead $R$. salmoninarum with detectable levels of DNA (Miriam et al. 1997). In addition, the nested PCR cannot provide a measure of the concentration of $R$. salmoninarum in a positive sample. Thus, the biological consequences of these PCR findings remain inconclusive with respect to $\mathrm{BKD}$ management programs, such as broodstock segregation, that rely on selecting egg lots from parents with undetectable or low levels of $R$. salmoninarum infection to interrupt vertical transmission.

Acknowledgements. This work was supported by contract no. E86970068 from the U.S. Department of the Army, Corps of Engineers, and by the U.S. Geological Survey. The authors thank Lynn Applegate and Connie McKibben for their technical support, and Drs Diane Elliott and Jim Winton for their critical reviews of the manuscript.

\section{LITERATURE CITED}

Austin B, Bucke D, Feist S, Rayment J (1985) A false positive reaction in the indirect fluorescent antibody test for Renibacterium salmoninarum with a 'coryneform' organism. Bull Eur Assoc Fish Pathol 5:8-9

Bandin I, Santos Y, Barja JL, Toranzo AE (1993) Detection of a common antigen among Renibacterium salmoninarum, Corynebacterium aquaticum, and Carnobacterium piscicola by the western blot technique. $\mathrm{J}$ Aquat Anim Health 5:172-176

Barlough JE, McDowell TS, Milani A, Bigornia L, Slemenda SB, Pieniazek NJ, Hedrick RP (1995) Nested polymerase chain reaction for detection of Enterocytozoon salmonis genomic DNA in chinook salmon Oncorhynchus tshawytscha. Dis Aquat Org 23:17-23

Benediktsdóttir E, Helgason S, Gudmundsdóttir S (1991) Incubation time for the cultivation of Renibacterium salmoninarum from Atlantic salmon, Salmo salar L., broodfish. J Fish Dis 14:97-102
Benvenisty N, Reshef L (1986) Direct introduction of genes into rats and expression of the genes. Proc Natl Acad Sci USA 83:9551-9555

Brown LL, Evelyn TPT, I wama GK, Nelson WS, Levine RP (1995) Bacterial species other than Renibacterium salmoninarum cross-react with antisera against $R$. salmoninarum but are negative for the p57 gene of $R$. salmoninarum as detected by the polymerase chain reaction (PCR). Dis Aquat Org 21:227-231

Brown LL, Iwama GK, Evelyn TPT, Nelson WS, Levine RP (1994) Use of the polymerase chain reaction (PCR) to detect DNA from Renibacterium salmoninarum within individual salmonid eggs. Dis Aquat Org 18:165-171

Bruno DW (1988) The relationship between auto-agglutination, cell surface hydrophobicity and virulence of the fish pathogen Renibacterium salmoninarum. FEMS Microbiol Lett 51:135-140

Daly JG, Stevenson RMW (1987) Hydrophobic and haemagglutinating properties of Renibacterium salmoninarum. J Gen Microbiol 133:3575-3580

Dixon PF (1985) Rapid detection and identification of the fish pathogen by the enzyme-linked immunosorbent assay (ELISA). In. Ellis AE (ed) Fish and shellfish pathology. Academic Press, London, p 11-16

Dixon PF (1987) Detection of Renibacterium salmoninarum by the enzyme-linked immunosorbent assay (ELISA). J Appl Ichthyol 3:77-82

Elliott DG, Barila TY (1987) Membrane filtration-fluorescent antibody staining procedure for detecting and quantifying Renibacterium salmoninarum in coelomic fluid of chinook salmon (Oncorhynchus tshawytscha). Can J Fish Aquat Sci 44:206-210

Elliott DG, McKibben CL (1997) Comparison of two fluorescent antibody techniques (FATs) for detection and quantification of Renibacterium salmoninarum in coelomic fluid of spawning chinook salmon Oncorhynchus tshawytscha. Dis Aquat Org 30:37-43

Elliott DG, Pascho RJ, Jackson LM, Matthews GM, Harmon JR (1997) Renibacterium salmoninarum in spring-summer chinook salmon smolts at dams on the Columbia and Snake Rivers. J Aquat Anim Health 9:114-126

Evelyn TPT (1977) An improved growth medium for the kidney disease bacterium and some notes on using the medium. Bull Off Int Epizoot 87:511-513

Evelyn TPT, Prosperi-Porta L, Ketcheson JE (1986) Experimental intra-ovum infection of salmonid eggs with Renibacterium salmoninarum and vertical transmission of the pathogen with such eggs despite their treatment with erythromycin. Dis Aquat Org 1:197-202

Evenden AJ, Grayson TH, Gilpin ML, Munn CB (1993) Renibacterium salmoninarum and bacterial kidney diseasethe unfinished jigsaw. Annu Rev Fish Dis 87-104

Fryer JL, Lannan CN (1993) The history and current status of Renibacterium salmoninarum, the causative agent of bacterial kidney disease in Pacific salmon. Fish Res 17:15-33

Griffiths SG, Lynch WH (1991) Instability of the major soluble antigen produced by Renibacterium salmoninarum. J Fish Dis 14:55-66

Gudmundsdóttir S, Benediktsdóttir E, Helgason S (1993) Detection of Renibacterium salmoninarum in salmonid kidney samples: a comparison of results using doublesandwich ELISA and isolation on selective medium. J Fish Dis 16:185-195

Gudmundsdóttir S, Helgason S, Benediktsdóttir E (1991) Comparison of the effectiveness of three different growth media for primary isolation of Renibacterium salmoninarum from Atlantic salmon. Salmo salar L., broodfish 
J Fish Dis 14:89-96

Hariharan H. Qian B, Despres B, Kibenge FS, Heaney SB, Rainnie DJ (1995) Development of a specific biotinylated DNA probe for the detection of Renibacterium salmoninarum. Can J Vet Res 59:306-310

Jansson E, Hongslo T, Hoglund J, Ljungberg O (1996) Comparative evaluation of bacterial culture and two ELISA techniques for the detection of Renibacterium salmonnarum antigens in salmonid kidney tissues. Dis Aquat Org 27:197-206

Kwok S, Higuchi R (1989) Avoiding false positives with PCR. Nature 339: 237

Lee IM, Bartoszyk IM, Gundersen DE, Mogen B, Davis RE (1997) Nested PCR for ultrasensitive detection of the potato ring rot bacterium, Clavibacter michiganensis, subsp. sepedonicus. Appl Environ Microbiol 63:2625-2630

Leon G, Martinez MA, Etchegaray JP, Vera MI, Figuera J, Krauskopf M (1994a) Specific DNA probes for the identification of the fish pathogen, Renibacterium salmoninarum. World J Microbiol Biotechnol 10:149-153

León G, Maulén N, Figuera J, Villanueva J, Roơríguez $C$, Vera Ml, Krauskopf M (1994b) A PCR-based assay for the identification of the fish pathogen Renibacterium salmoninarum. FEMS Microbiol Lett 115:131-136

Magnússon $\mathrm{HB}$, Fridjónsson $\mathrm{OH}$, Andrésson OS, Benediktsdóttir E, Gudmundsdóttir S, Andrésdóttir V (1994) Renibacterium salmoninarum, the causative agent of bacterial kidney disease in salmonid fish, detected by nested reverse transcription-PCR of 16S rRNA sequences. Appl Environ Microbiol 60:4580-4583

Mattsson JG, Gersdorf H, Jansson E, Hongslo T, Góbel UB, Johansson KE (1993) Rapid identification of Renibacterium salmoninarum using an oligonucleotide probe complementary to 16S rRNA. Mol Cell Probes 7:25-33

Maule AG, Rondorf DW, Beemen J, Haner P (1996) Incidence of Renibacterium salmoninarum infections in juvenile hatchery spring chinook salmon in the Columbia and Snake Rivers. J Aquat Anim Health 8:37-46

McIntosh D, Meaden PG, Austin B (1996) A simplified PCRbased method for the detection of Renibacterium salmoninarum utilizing preparations of rainbow trout (Oncorhynchus mykiss, Walbaum) lymphocytes. Appl Environ Microbiol 62:3929-3932

Meyers TR, Short S, Farrington C, Lipson K, Geiger HJ, Gates $R$ (1993) Comparison of the enzyme-linked immunosorbent assay (ELISA) and the fluorescent antibody test (FAT) for measuring the prevalences and levels of Renibacterium salmoninarum in wild and hatchery stocks of

Editorial responsibility: David Bruno,

Aberdeen, Scotland, UK salmonid fishes in Alaska, USA. Dis Aquat Org 16: $181-189$

Miriam A, Griffiths SG, Lovely JE, Lynch WH (1997) PCR and Probe-PCR assays to monitor broodstock Atlantic Salmon (Salmo salar L.) ovarian fluid and kidney tissue for the presence of DNA of the fish pathogen Renibacterium salmoninarum. J Clin Microbiol 35:1322-1326

Mooney J, Powell E, Clabby C, Powell R (1995) Detection of Aeromonas salmonicida in wild Atlantic salmon using a specific DNA probe test. Dis Aquat Org 21:131-135

Pascho RJ, Chase D, McKibben CL (1998) Comparison of the membrane-filtration fluorescent antibody test, enzymelinked immunosorbent assay, and the polymerase chain reaction to detect Renibacterium salmoninarum in salmonid ovarian fluid. J Vet Diagn Invest 10:60-66

Pascho RJ, Elliott DG, Mallett RW, Mulcahy D (1987) Comparison of five techniques for the detection of Renibacterium salmoninarum in adult coho salmon. Trans Am Fish Soc 116:882-890

Pascho RJ, Elliott DG, Streufert JM (1991) Brood stock segregation of spring chinook salmon Oncorhynchus tshawytscha by the use of the enzyme-linked immunosorbent assay (ELISA) and the fluorescent antibody technique (FAT) affects the prevalence and levels of Renibacterium salmoninarum infection in progeny. Dis Aquat Org 12: $25-40$

Pascho RJ, Mulcahy D (1987) Enzyme-linked immunosorbent assay for a soluble antigen of Renibacterium salmoninarum, the causative agent of salmonid bacterial kidney disease, Can J Fish Aquat Sci 44:183-191

Porter-Jordan K, Rosenberg El, Keiser JF, Gross JD, Ross AM, Nasim S, Garrett CT (1990) Nested polymerase chain reaction assay for the detection of Cytomegalovirus overcomes false positives caused by contamination with fragmented DNA. J Med Virol 30:85-91

Rockey DD, Gilkey LL, Wiens GD, Kaattari SL (1991) Monoclonal antibody-based analysis of the Renbacterium salmoninarum p57 protein in spawning chinook and coho salmon. J Aquat Anim Health 3:23-30

Saiki RK (1992) The design and optimization of the PCR. In: Erlich HA (ed) PCR technology, principles and applications for DNA amplification. Oxford University Press, New York, p 7-16

Wood PA, Wiens GD, Rohovec JS, Rockey DD (1995) Identification of an immunologically cross-reactive 60-Kilodalton Renibacterium salmoninarum protein distinct from p57: implications for immunodiagnostics. J Aquat Anim Health 7:95-103

Submitted: April 4, 1998; Accepted: July 23, 1998

Proofs received from author(s): October 16, 1998 